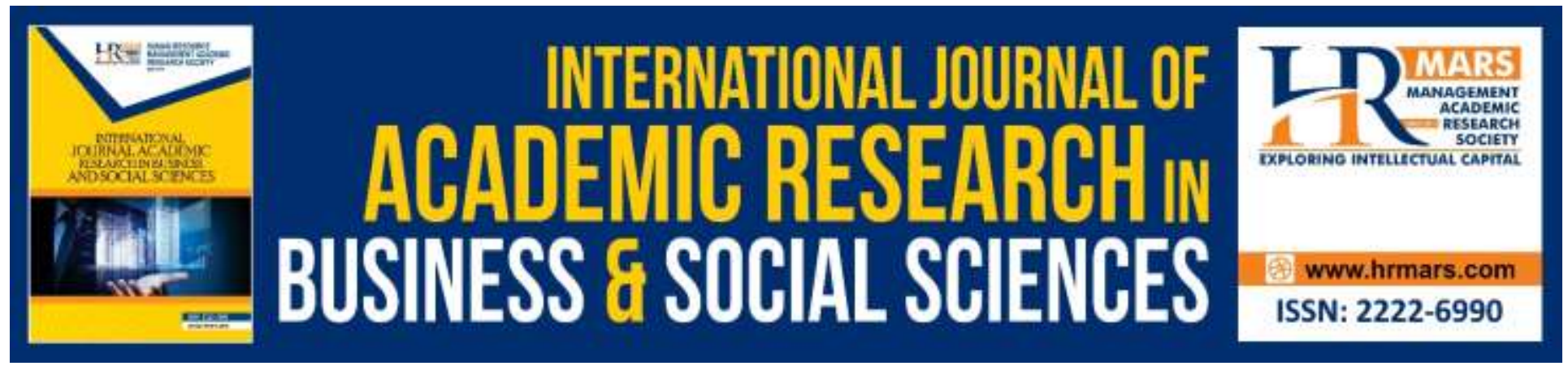

\title{
Validity and Reliability of Tactical Skills Assessment Instrument for Talent Identification among Malaysian Male Young Football Players
}

Khairul Sham Hanapiah, Ahmad Hashim \& Zulakbal Abd Karim

To Link this Article: http://dx.doi.org/10.6007/IJARBSS/v9-i11/6550

DOI: 10.6007/IJARBSS/v9-i11/6550

Received: 10 October 2019, Revised: 30 October 2019, Accepted: 03 November 2019

Published Online: 13 November 2019

In-Text Citation: (Hanapiah, Hashim, \& Karim, 2019)

To Cite this Article: Hanapiah, K. S., Hashim, A., \& Karim, Z. A. (2019). Validity and Reliability of Tactical Skills Assessment Instrument for Talent Identification among Malaysian Male Young Football Players. International Journal of Academic Research in Business and Social Sciences, 9(11), 313-322.

Copyright: (C) 2019 The Author(s)

Published by Human Resource Management Academic Research Society (www.hrmars.com)

This article is published under the Creative Commons Attribution (CC BY 4.0) license. Anyone may reproduce, distribute, translate and create derivative works of this article (for both commercial and non-commercial purposes), subject to full attribution to the original publication and authors. The full terms of this license may be seen at: http://creativecommons.org/licences/by/4.0/legalcode

Vol. 9, No. 11, 2019, Pg. 313 - 322

Full Terms \& Conditions of access and use can be found at http://hrmars.com/index.php/pages/detail/publication-ethics 


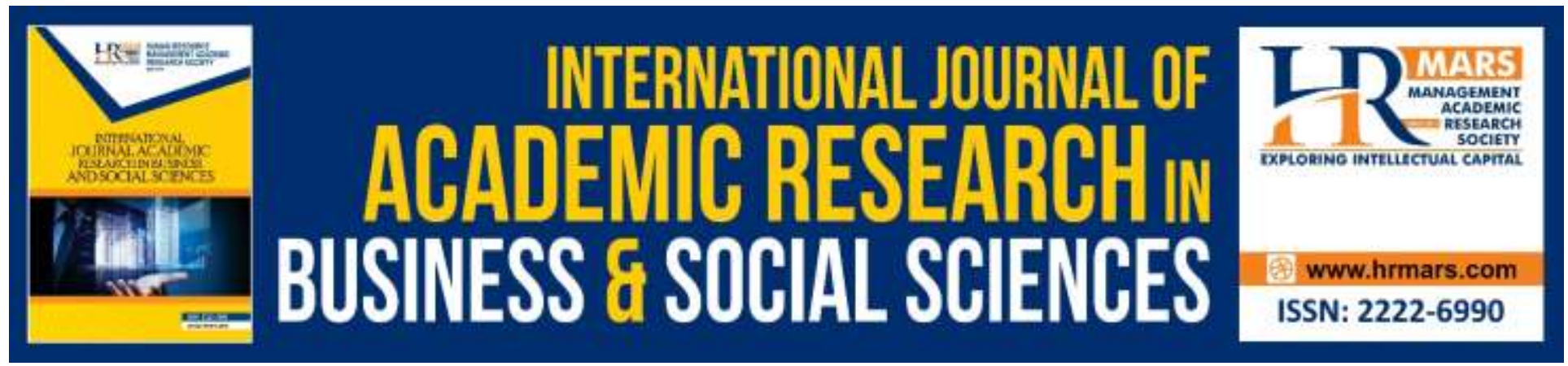

\title{
Validity and Reliability of Tactical Skills Assessment Instrument for Talent Identification among Malaysian Male Young Football Players
}

\author{
Khairul Sham Hanapiah, Ahmad Hashim \& Zulakbal Abd Karim \\ Faculty of Sports Science and Coaching, Sultan Idris Education University, Tanjong Malim, Perak, \\ Malaysia \\ Email: khairulsham@yahoo.com
}

\begin{abstract}
The main aim of this study is to obtain the validity and reliability of tactical skills assessment instrument for talent identification among Malaysian male young football players aged 13 to 14 years old. Five sub attributes are used to measure the attributes of tactical skills, which are offensive skills, one-on-one skills, defensive skills, defensive to offensive transition and offensive to defensive transition. A total of 120 male football players aged 13 to 14 years old who underwent training under the Malaysia National Football Development Programme were selected as study samples. Pearson correlation analysis were used to obtain validity of field experts. Cronbach's alpha analysis were used to obtain reliability coefficient of the assessment instrument on tactical skills. Factor analysis was used to obtain the construct validity of the questionnaire items. The factor analysis results showed 20 questionnaire items are valid from the overall 38 items constructed. The result of Pearson correlation analysis shows the value of field experts validity is $r=.83$. Cronbach's alpha analysis of the questionnaire items obtained high reliability value of $\alpha=.91$ and the internal consistency coefficient for each sub attributes are offensive skills ( $\alpha=.82$ ), one-on-one skills $(\alpha=.81)$, defensive skills $(\alpha=.84)$, defensive to offensive transition $(\alpha=.82$ ) and offensive to defensive transition $(\alpha=.81)$. The scale can be considered a suitable instrument to assess tactical skill levels among male young soccer players aged 13 to 14 years old.

Keywords: Validity, Reliability, Tactical Skills, Offensive Skills, One-on-One Skills, Defensive Skills, Defensive to Offensive Transition and Offensive to Defensive Transition.
\end{abstract}


INTERNATIONAL JOURNAL OF ACADEMIC RESEARCH IN BUSINESS AND SOCIAL SCIENCES

Vol. 9, No. 11, November, 2019, E-ISSN: 2222-6990 @ 2019 HRMARS

\section{Introduction}

Tactical skills is a very crucial aspect to achieve success in modern football games (Rein \& Memmert, 2016). According to Kannekens, Elferink-gemser, \& Visscher (2009), in football, tactical skills refer to the ability of an individual player to perform the right action at the right moment and quickly adapt to new configurations of play and the circulation of the ball. Appropriate directed tactical skills is a strategy and tactic which is used in challenging the opponent's. Strategy is a plan such as instruction and certain position which is used to face different game situations, while tactics are a punctual adaptation to new configurations of play and to the circulation of the ball (Grehaigne \& Godbout, 1995).

In psychology cognitive, Adaptive Control of Thought theory, Rational (ACT-R; Anderson et al., 2004) has developed two types of knowledge which is declarative and procedural that influence the process such as observation, visual behavior, expectation, reaction selection and the implementation. Tactical skills is dependent to various cognitive competency which is based on declarative and procedural knowledge that adheres to the real situation of games (Thomas et al., 1986). Declarative knowledge (knowing what to do) is a knowledge about knowledge of the rules and goals of the games (McPherson, 1994; Williams \& Davids, 1995) especially related to the work memory and ability to identify and remembering specific patterns (Cardoso et al., 2019). However, procedural knowledge (doing it) is the selection of an appropriate action within the context of the games (McPherson, 1994) which is related to the ability to understand the needs of the games environment and to act in advance for an appropriate games (Cardoso et al., 2019).

In the context of the game, the skill of making decision of right action and the ability of executing the complex sports skill is crucial (Elferink-Gemser et al., 2010; McPherson, 1994). Olivares, Clemente, \& Villora (2016) found out that in invasion games like football, the player decides and execute the tactical skills in two different phases which are attacking and defending phase. Attacking phase is when the team keeps possession and control of play, trying to create situations that result in the completion of the objective while defending phase is when the team is not in possession and tries to regain control, impeding their rival's and the ball's progress towards their goal, in order to prevent the opponents from achieving their objective. Since 1987, many research have tried to explain the differences of tactical knowledge between players and different level of expertise (Cardoso et al., 2019; Den Hartigh et al., 2017; Elferink-Gemser et al., 2010; French \& Thomas, 1987). It is confirmed that the expertise in sports is dependent to the development factor of specific sports cognitive and the accurate and efficient movement pattern implementation (Williams et al., 1993).

Malaysian football philosophy or DNA is applied through the National Football Development Program which needs players who are competence of the games concept. Some of the applied tactical skills are the offensive organization, defensive organization, individual ability, set pieces, shifting from defense to offense and shifting from offense to defense (Kementerian Belia dan Sukan Malaysia, 2014). In line with the Malaysian football philosophy, researchers constructed the questionnaire of tactical skills assessment following the tactical principles in football (Asian Football Confederation, 2000). The questionnaire instrument refers to the way of players doing self-assessment about the awareness level of tactical skills based on the tactical 
INTERNATIONAL JOURNAL OF ACADEMIC RESEARCH IN BUSINESS AND SOCIAL SCIENCES

Vol. 9, No. 11, November, 2019, E-ISSN: 2222-6990 ㄷ 2019 HRMARS

principles in football. High performing football players must possess a high level of tactical skills awareness to be applied with national football game principles.

\section{Objective}

This study aims to obtain the validity and reliability of tactical skills assessment instrument for talent identification among Malaysian male football players aged 13 to 14 years old.

\section{Methodology}

This cross-sectional study is divided into three phases. The first phase started with the construction of tactical skills assessment questionnaire instrument and obtaining validity of the field experts. Second phase is the determination of the reliability of the questionnaire items. While the third phase involves the measurement of construct validity of the questionnaire items. The target population for this study is the male football players aged 13 to 14 years old who has been trained under the Malaysia National Football Development Program in 2018/2019. The researchers randomly selected 120 male football players between the age of 13 and 14 years old after taking into consideration of absence or mortality factor (Konting, 2009) and the sample size of minimum 100 participants for factor analysis (Hashim, 2014).

In this study, the dependent variable is the football playing ability score. While independent variables are the scores of each sub attributes of offensive skills, one-on-one skills, and defensive skills, defensive to offensive transition and offensive to defensive transition. Figure 1 shows the study variables. The researchers developed the questionnaire of assessment instrument on tactical skills by using the 5 points Likert scale $(1=$ never, $2=$ rarely, $3=$ sometimes, $4=$ often and $5=$ always). Tactical skills assessment instrument has 38 questionnaire items at the initial stage of the study to measure five sub attributes namely offensive skills, one-on-one skills, defensive skills, defensive to offensive transition and offensive to defensive transition. A total of 120 respondents were selected in this study to identify the validity and reliability of questionnaire items. 


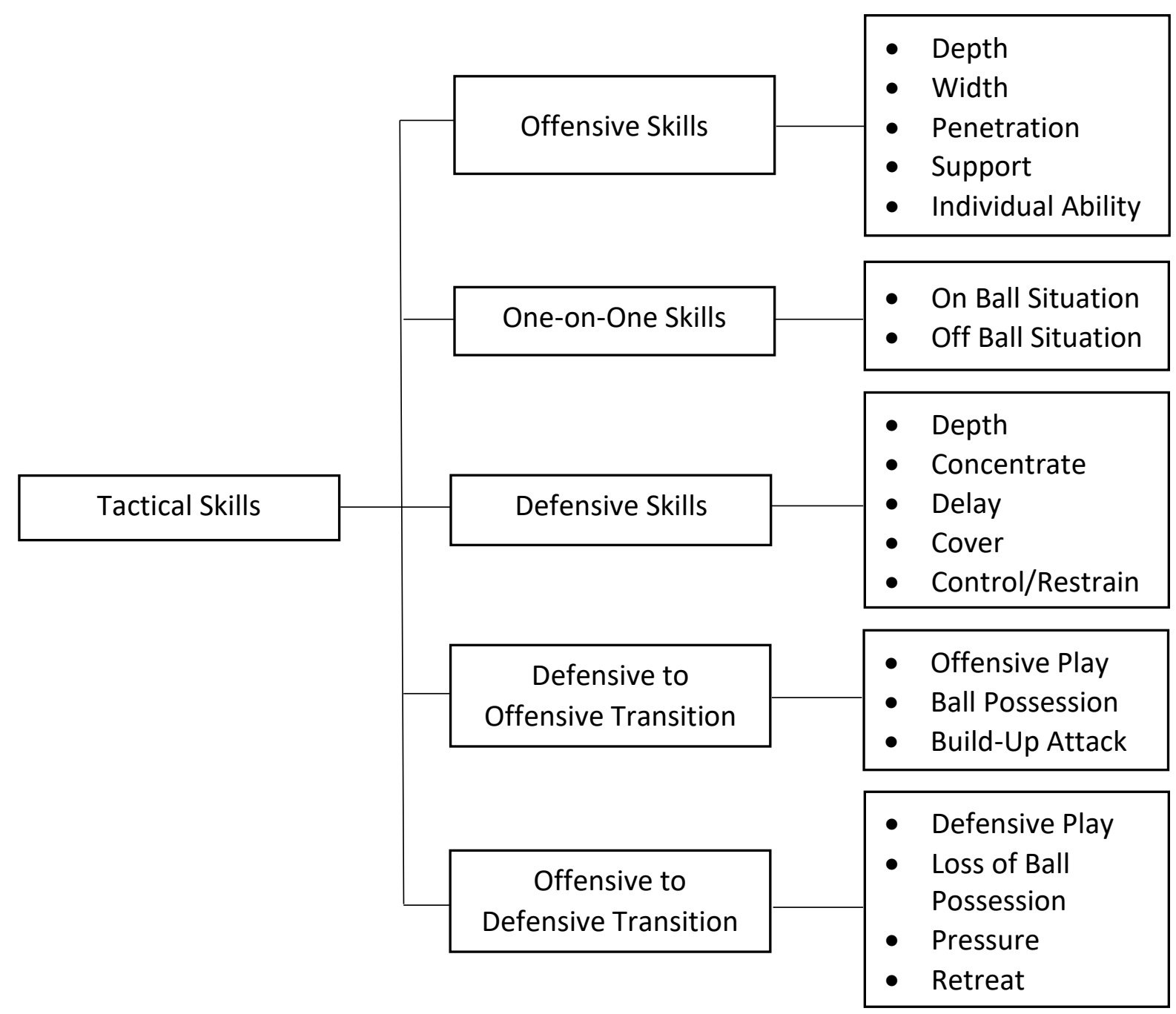

Figure 1. Variables of Study

\section{Data Analysis Procedures}

Statistical Package for the Social Sciences (SPSS) 21.0 version software was used to analyse the data of assessment instrument on tactical skills. Pearson correlation analysis was used to obtain the validity of field experts based on the consensus of the three expert panels. Cronbach' alpha analysis was used to obtain the questionnaire's reliability and internal consistency coefficient questionnaire items. Factor analysis attempts to identify a small set of factors that represents the underlying relationships among a group of related variables (Hashim, 2014; Pallant, 2010). 


\section{Results}

Based on the suggested formula of Noah \& Ahmad (2005) for expert panel evaluation on 10 questionnaire items being valued at scale 1 to 5 to verify the instrument of questionnaire, the value of field experts validity obtained is $r=.83$. A total of 38 questionnaires items have been developed to assess the performance of attributes namely tactical skills based on five sub attributes. The sub attributes are offensive skills, one-on-one skills, and defensive skills, defensive to offensive transition and offensive to defensive transition. Based on the factor analyses results, only 20 items were accepted as valid tactical skills questionnaire items. Cronbach's alpha analysis of the questionnaire items obtained high reliability value of $\alpha=.91$ and the internal consistency coefficient for each sub attributes are offensive skills $(\alpha=.82)$, one-on-one skills $(\alpha=.81)$, defensive skills $(\alpha=.84)$, defensive to offensive transition $(\alpha=.82)$ and offensive to defensive transition $(\alpha=.81)$. Table 1,2 and 3 shows the results of factor analysis.

Table 1. Bartlett's dan Kaiser-Meyer-Olkin (KMO) Test Results

\begin{tabular}{lrr}
\hline Kaiser-Meyer-Olkin Measure of Sampling Adequacy. & .723 \\
& Approx. Chi-Square & 2185.193 \\
Bartlett's Test of Sphericity & Df & 703 \\
& Sig. & .000 \\
\hline
\end{tabular}

Kaiser's criterion technique was used to determine the number of components. Components with only one or more eigenvalue were selected in this analysis. There are 12 analysis components with more than one eigenvalue. Finding in Table 1 shows the results of all 38 attribute analysis components on tactical skills explained 72.3 per cent variance. The matrix component shows loading in each line expressed that each questionnaire item's correlation with sub attributes comprising offensive skills, one-on-one skills, defensive skills, defensive to offensive transition and offensive to defensive transition.

Table 2. Total Variance Explained

\begin{tabular}{cccc}
\hline Component & \multicolumn{3}{c}{ Rotation Sums of Squared Loadings } \\
\cline { 2 - 4 } & Total & \% of Variance & Cumulative \% \\
\hline 1 & 4.725 & 12.434 & 12.434 \\
2 & 4.145 & 10.908 & 23.341 \\
3 & 3.821 & 10.056 & 33.397 \\
4 & 3.106 & 8.174 & 41.571 \\
5 & 2.921 & 7.688 & 49.259 \\
\hline
\end{tabular}

Extraction Method: Principal Component Analysis.

To maintain all the five components for the next analysis, the researchers used the varimax rotation method to minimise the number of questionnaire items which has high correlation on every factor. According to Tabachnick \& Fidell (2007), results based on orthogonal 
rotation is more easy to be translated and reported. Table 2 shows the result of five components rotation using the varimax rotation method. The result shows the first component explained 12.43 per cent of variance, the second component explained 10.91 per cent of variance, the third component explained 10.06 per cent of variance, the fourth component explained 8.17 per cent of variance and the fifth component explained 7.69 per cent of variance. Total amount of variance available which could be explained by all five components was 49.26 per cent variance and the figure remained after rotation.

Table 3 shows loading factor more than $r=.60$ for five component of tactical skills questionnaire. The high matric correlation coefficient value of a test on a measured factor indicated close relation with the factor (Tabachnick \& Fidell, 2007). Based on the Principal Component Analysis, only 20 items showed high communality score from overall 38 questionnaire items. Column one represented assessment instrument of sub attributes on offensive skills, the second represented one-on-one skills, the third represented defensive skill, the fourth represented defensive to offensive transition and the fifth represented offensive to defensive transition. According to Pallant (2010), based on this significant results $(r=.60), 20$ items in this analysis are considered valid for attribute assessment instrument on tactical skills in this study.

Table 3. Construct Validity for Rotated Component Matrix Component Rotated Component Matrix ${ }^{a}$

\begin{tabular}{lccccc}
\hline Item & \multicolumn{5}{c}{ Component } \\
\cline { 2 - 6 } & 1 & 2 & 3 & 5 & 5 \\
\hline S14 & .713 & & & & \\
S15 & .688 & & & & \\
S13 & .665 & & & & \\
S12 & .637 & & & & \\
S11 & .610 & & & &
\end{tabular}

S9

S10

S8

S2

S31 
S24

S3

S23

S6

S5

S22

S4

S25

S27

S19

S26

S20

S1

S28

S17

S16

S18

S37

S38

Extraction Method: Principal Component Analysis.

Rotation Method: Varimax with Kaiser Normalization.

a. Rotation converged in 10 iterations.
.623

.604

\section{Discussion}

Factor analysis is the most suitable statistical analysis to obtain the construct validity of the tactical skills assessment instrument. Factor analysis was conducted by following three main steps; firstly, assessment of the suitability of the data for factor analysis, secondly, factor extraction and lastly, factor rotation and interpretation (Pallant, 2010). According to Hashim (2014), the aim of factor analysis is to obtain information pertaining to questionnaire items and their relationship with every components tested. Out of 38 questionnaire items, a total of 20 found has high validity and reliability in measuring awareness level of tactical skills among Malaysian male football players aged 13 to 14 years old.

\section{Conclusion}

This study has developed tactical skills assessment instrument for talent identification among Malaysian male young football players. The result in this study indicated that five factors (offensive skills, one-on-one skills, defensive skills, defensive to offensive transition and offensive to defensive transition) were valid and reliable for Malaysian male young football players aged 13 to 14 years old. This instrument will enable football coaches and talent scouts to collect information that could be valuable in assessing the awareness level of players' tactical skills in talent development programs. 
To assess the players' tactical skills among young football players aged 13 to 14 years old, researchers has only used cross-sectional approach. Therefore, future research should consider longitudinal study that focuses on the tactical skills among elite youth football players from age 13 to 15 years playing in different field positions. This is because different field positions rely on different skills in terms of declarative and procedural knowledge within the context of the game.

\section{Corresponding Authors}

Khairul Sham Hanapiah

PhD Candidate, Sultan Idris Education University, Faculty of Sports Science and Coaching, 35900 Tanjong Malim, Malaysia.

Email: khairulsham@yahoo.com

\section{References}

Anderson, J. R., Bothell, D., Byrne, M. D., Douglass, S., Lebiere, C., \& Qin, Y. (2004). An integrated theory of the mind. Psychological Review, 111(4), 1036-1060.

Asian Football Confederation. (2000). " $B$ " certificate coaching manual (3rd ed.). Kuala Lumpur: Asian Football Confederation.

Cardoso, F. D. S. L., Gonzalez-Vıllora, S., Guilherme, J., \& Teoldo, I. (2019). Young soccer players with higher tactical knowledge display lower cognitive effort. Perceptual and Motor Skills, 126(3), 499-514.

Costa, I. T. da, Silva, J. M. G. D, Greco, P. J., \& Mesquita, I. (2009). Tactical principles of soccer: Concepts and application. Revista Motriz, 15(3), 657-668.

Den Hartigh, R. J. R., Steen, V. D. S., Hakvoort, B., Frencken, W. G. P., \& Lemmink, K. A. P. M. (2017). Differences in game reading between selected and non-selected youth soccer players. Journal of Sports Sciences, 36(4), 422-428.

Elferink-Gemser, M. T., Kannekens, R., Lyons, J., Tromp, Y., \& Visscher, C. (2010). Knowing what to do and doing it: Differences in self-assessed tactical skills of regional, sub-elite, and elite youth field hockey players. Journal of Sports Sciences, 28(5), 521-528.

French, K. E., \& Thomas, J. R. (1987). The relation of knowledge development to children's basketball performance. Journal of Sport Psychology, 9(1), 15-32.

Grehaigne, J.-F., \& Godbout, P. (1995). Tactical knowledge in team sports from a constructivist and cognitivist perspective. Quest, 47(4), 490-505.

Hashim, A. (2014). Panduan analisis data secara efisien: Panduan lengkap berajah untuk menganalisis data. Bandar Baru Bangi: Dubook Press Sdn Bhd.

Kannekens, R., Elferink-gemser, M. T., \& Visscher, C. (2009). Tactical skills of world-class youth soccer teams. Journal of Sports Sciences, 27(8), 807-812.

Kementerian Belia dan Sukan Malaysia. (2014). Pelan pembangunan bola sepak negara fasa 1: 2014-2020. Putrajaya: Kementerian Belia dan Sukan Malaysia.

Konting, M.M. (2009). Kaedah penyelidikan pendidikan. Ampang: Dawama Sdn. Bhd.

McPherson, S. L. (1994). The development of sport expertise: Mapping the tactical domain. 
Quest, 46(2), 223-240.

Noah, S. M., \& Ahmad, J. (2005). Pembinaan modul: Bagaimana membina modul latihan dan modul akademik. Serdang: Penerbit Universiti Putra Malaysia.

Olivares, J. S., Clemente, F. M., \& Villora, S. G. (2016). Tactical expertise assessment in youth football using representative tasks. SpringerPlus, 5(1), 1301-1309.

Pallant, J. (2010). SPSS survival manual: A step by step guide to data analysis using SPSS (4th ed.). New York, NY: McGraw-Hill Companies.

Rein, R., \& Memmert, D. (2016). Big data and tactical analysis in elite soccer: Future challenges and opportunities for sports science. SpringerPlus, 5(1), 1410-1423.

Tabachnick, B. G., \& Fidell, L. S. (2007). Using multivariate statistics (4th ed.). Bosrom: Pearson Educational, Inc.

Thomas, J. R., French, K. E., \& Humphries, C. A. (1986). Knowledge development and sport skill performance: Directions for motor behavior research. Journal of Sport Psychology, 8(4), 259-272.

Williams, A. M., Davids, K., Burwittz, L., \& Williams, J. (1993). Cognitive knowledge and soccer performance. Perceptual \& Motor Skills, 76(2), 579-593.

Williams, M., \& Davids, K. (1995). Declarative knowledge in sport: A by-product of experience or a characteristic of expertise? Jornal of Sport \& Exercise Psychology, 17(3), 259-275. 